\title{
Understanding Neuromuscular Health and Disease: Advances in Genetics, Omics, and Molecular Function
}

Duddy, W., \& Duguez, S. (2021). Understanding Neuromuscular Health and Disease: Advances in Genetics, Omics, and Molecular Function. Journal of Personalized Medicine, 11(5), [438].

https://doi.org/10.3390/jpm11050438

Link to publication record in Ulster University Research Portal

Published in:

Journal of Personalized Medicine

Publication Status:

Published (in print/issue): 20/05/2021

DOI:

10.3390/jpm11050438

Document Version

Publisher's PDF, also known as Version of record

\section{General rights}

Copyright for the publications made accessible via Ulster University's Research Portal is retained by the author(s) and / or other copyright owners and it is a condition of accessing these publications that users recognise and abide by the legal requirements associated with these rights.

\section{Take down policy}

The Research Portal is Ulster University's institutional repository that provides access to Ulster's research outputs. Every effort has been made to ensure that content in the Research Portal does not infringe any person's rights, or applicable UK laws. If you discover content in the Research Portal that you believe breaches copyright or violates any law, please contact pure-support@ulster.ac.uk. 


\title{
Editorial \\ Understanding Neuromuscular Health and Disease: Advances in Genetics, Omics, and Molecular Function
}

\author{
William J. Duddy *(D) and Stephanie Duguez *(D) \\ Northern Ireland Center for Stratified/Personalized Medicine, Ulster University, Glenshane Road, \\ Derry-Londonderry BT47 6SB, UK \\ * Correspondence: w.duddy@ulster.ac.uk (W.J.D.); s.duguez@ulster.ac.uk (S.D.)
}

check for updates

Citation: Duddy, W.J.; Duguez, S. Understanding Neuromuscular Health and Disease: Advances in Genetics, Omics, and Molecular Function. J. Pers. Med. 2021, 11, 438. https://doi.org/10.3390/jpm11050438

Received: 30 April 2021

Accepted: 18 May 2021

Published: 20 May 2021

Publisher's Note: MDPI stays neutral with regard to jurisdictional claims in published maps and institutional affiliations.

Copyright: (C) 2021 by the authors. Licensee MDPI, Basel, Switzerland. This article is an open access article distributed under the terms and conditions of the Creative Commons Attribution (CC BY) license (https:// creativecommons.org/licenses/by/ $4.0 /)$.
The field of neuromuscular research has seen considerable recent advances in the molecular and cellular understanding of muscle biology, and the treatment of neuromuscular disease. These advances are at the forefront of modern molecular methodologies, often integrating across wet-lab cell and tissue models, dry-lab computational approaches, and clinical studies. The continuing development and application of multiomics methods offer particular challenges and opportunities, not least in the potential for personalized medicine. More than 500 different genes are known to be associated with neuromuscular disorders [1], and the identification of causative mutations has allowed the development of personalized therapies [1,2]. However, even if great progress has been made during the last two decades in different subgroups of neuromuscular disorders, there are still numerous challenges to resolve, such as the optimization of therapeutic knock-down strategies [3], targeting specific muscles and/or tissues of the nervous system [1], identifying genetic modifiers that can impair a therapeutic strategy [2], targeting common pathways being affected in different patient subgroups for a given disease [4,5], or understanding the impact of neuromuscular disorders on other tissues that could be affected but may be understudied.

This Special Issue, entitled "Understanding Neuromuscular Health and Disease: Advances in Genetics, Omics, and Molecular Function", encompasses some 15 publications from colleagues working on a diverse range of neuromuscular diseases, including Duchenne muscular dystrophy [6-9], facioscapulohumeral dystrophy [3,10,11], amyotrophic lateral sclerosis [4,5,12], spinal muscular atrophy [2], Emery-Dreifuss muscular dystrophy [13], and rheumatoid arthritis [14]. Looking across diseases, several themes are recurrent, such as the efforts to identify genotype-phenotype correlations in DMD $[6,7,9]$ and ALS $[4,5]$, the quest for effective biomarkers in many neuromuscular conditions $[2,8,10,14]$, and the use of genomic and multi-omic approaches towards better ways to identify biomarkers and to understand disease $[10,12,13]$.

The search for genotype-phenotype correlations can be aimed at the improved understanding of disease $[4,5,7,9]$, but may also be relevant to potential therapeutic outcomes [6] Of relevance to this Special Issue are genotype-phenotype correlations in DMD $[6,7,9]$ and in ALS [4,5]. It is interesting to contrast the state of these investigations in these two conditions, differences which are related to the underlying genetics: DMD being due to mutations at a single gene, and therefore correlations being sought between clinical outcomes and specific mutation patterns within that gene [6,7,9]; ALS being a disease of unclear aetiology for the majority of patients and the focus of these genotype-phenotype investigations thus being on the relationship of different genes and their functional roles to the implicated mechanisms [4] or clinical outcomes of the condition [5].

The use of genomics and multi-omics approaches is a theme which itself cuts across the aims of current research, from the overlay of multiple omics data to achieve a global perspective and new understanding of Emery-Dreifuss muscular dystrophy [13], to the identification of novel circulating miRNA and protein biomarkers for FSHD using multiomics [10], through to the application of machine learning to the genomics of ALS, which 
is aimed at understanding the molecular basis of this disease (and is also relevant to genotype-phenotype correlations) [12]. Deciphering the pathways and gene mutations involved in neuromuscular diseases may allow for the development of computational models helping our understanding of muscle pathologies, which could enable preclinical studies of neuromuscular diseases in the context of personalized medicine [15].

Aside from therapeutic strategy development, the use of biomarkers may be critical as disease trackers for the development of effective therapeutics (for example, in FSHD [10]), but also to the personalized tailoring of existing treatments (in DMD [8], and in rheumatoid arthritis [14]), and may prove useful in a broad sense for improved stratification, diagnosis, and/or treatment (e.g., in adult SMA [2]).

We hope that studies such as these, that integrate modern molecular methodologies across cell and tissue models, computational approaches, and clinical studies, will continue to drive progress towards improved neuromuscular health and treatments for these often severe diseases.

Funding: Not applicable.

Institutional Review Board Statement: Not applicable.

Informed Consent Statement: Not applicable.

Data Availability Statement: Not applicable.

Acknowledgments: We wish to thank all the authors who contributed their work, and in so doing made the Special Issue a success. We also wish to thank the staff of JPM for their excellent support throughout the editorial process.

Conflicts of Interest: The authors declare no conflict of interest.

\section{References}

1. Buscara, L.; Gross, D.-A.; Daniele, N. Of rAAV and Men: From Genetic Neuromuscular Disorder Efficacy and Toxicity Preclinical Studies to Clinical Trials and Back. J. Pers. Med. 2020, 10, 258. [CrossRef] [PubMed]

2. Smeriglio, P.; Langard, P.; Querin, G.; Biferi, M.G. The Identification of Novel Biomarkers Is Required to Improve Adult SMA Patient Stratification, Diagnosis and Treatment. J. Pers. Med. 2020, 10, 75. [CrossRef] [PubMed]

3. Joubert, R.; Mariot, V.; Charpentier, M.; Concordet, J.P.; Dumonceaux, J. Gene Editing Targeting the DUX4 Polyadenylation Signal: A Therapy for FSHD? J. Pers. Med. 2020, 11, 7. [CrossRef] [PubMed]

4. Le Gall, L.; Anakor, E.; Connolly, O.; Vijayakumar, U.; Duddy, W.; Duguez, S. Molecular and Cellular Mechanisms Affected in ALS. J. Pers. Med. 2020, 10, 101. [CrossRef] [PubMed]

5. Connolly, O.; Le Gall, L.; McCluskey, G.; Donaghy, C.G.; Duddy, W.J.; Duguez, S. A Systematic Review of Genotype-Phenotype Correlation across Cohorts Having Causal Mutations of Different Genes in ALS. J. Pers. Med. 2020, 10, 58. [CrossRef] [PubMed]

6. Anwar, S.; He, M.; Lim, K.R.Q.; Maruyama, R.; Yokota, T. A Genotype-Phenotype Correlation Study of Exon Skip-Equivalent InFrame Deletions and Exon Skip-Amenable Out-of-Frame Deletions across the DMD Gene to Simulate the Effects of Exon-Skipping Therapies: A Meta-Analysis. J. Pers. Med. 2021, 11, 46. [CrossRef] [PubMed]

7. Lim, K.R.Q.; Nguyen, Q.; Yokota, T. Genotype-Phenotype Correlations in Duchenne and Becker Muscular Dystrophy Patients from the Canadian Neuromuscular Disease Registry. J. Pers. Med. 2020, 10, 241. [CrossRef] [PubMed]

8. Tawalbeh, S.; Samsel, A.; Gordish-Dressman, H.; Hathout, Y.; Investigators, C.-D.; Dang, U.J. Comparison of Serum Pharmacodynamic Biomarkers in Prednisone-Versus Deflazacort-Treated Duchenne Muscular Dystrophy Boys. J. Pers. Med. 2020, 10, 164. [CrossRef] [PubMed]

9. Sheikh, O.; Yokota, T. Advances in Genetic Characterization and Genotype-Phenotype Correlation of Duchenne and Becker Muscular Dystrophy in the Personalized Medicine Era. J. Pers. Med. 2020, 10, 111. [CrossRef] [PubMed]

10. Heier, C.; Zhang, A.; Nguyen, N.; Tully, C.; Panigrahi, A.; Gordish-Dressman, H.; Pandey, S.; Guglieri, M.; Ryan, M.; Clemens, P.; et al. Multi-Omics Identifies Circulating miRNA and Protein Biomarkers for Facioscapulohumeral Dystrophy. J. Pers. Med. 2020, 10, 236. [CrossRef] [PubMed]

11. Sidlauskaite, E.; Le Gall, L.; Mariot, V.; Dumonceaux, J. DUX4 Expression in FSHD Muscles: Focus on Its mRNA Regulation. J. Pers. Med. 2020, 10, 73. [CrossRef] [PubMed]

12. Vasilopoulou, C.; Morris, A.P.; Giannakopoulos, G.; Duguez, S.; Duddy, W. What Can Machine Learning Approaches in Genomics Tell Us about the Molecular Basis of Amyotrophic Lateral Sclerosis? J. Pers. Med. 2020, 10, 247. [CrossRef] [PubMed]

13. Vignier, N.; Muchir, A. An Omics View of Emery-Dreifuss Muscular Dystrophy. J. Pers. Med. 2020, 10, 50. [CrossRef] [PubMed] 
14. D'Cruz, L.G.; McEleney, K.G.; Tan, K.B.C.; Shukla, P.; Gardiner, P.V.; Connolly, P.; Conway, C.; Cobice, D.; Gibson, D.S. Clinical and Laboratory Associations with Methotrexate Metabolism Gene Polymorphisms in Rheumatoid Arthritis. J. Pers. Med. 2020, 10, 149. [CrossRef] [PubMed]

15. Speciale, A.A.; Ellerington, R.; Goedert, T.; Rinaldi, C. Modelling Neuromuscular Diseases in the Age of Precision Medicine. J. Pers. Med. 2020, 10, 178. [CrossRef] [PubMed] 